\title{
Influence of long-term hypoxia exposure on the energy metabolism of Solea solea. II. Intermediary metabolism in blood, liver and muscle*
}

\author{
Josef Dalla Via ${ }^{1}$, Guido van den Thillart ${ }^{2}$, Otello Cattani ${ }^{3}$, Albertus de Zwaan ${ }^{4}$ \\ ${ }^{1}$ Department of Zoology, University of Innsbruck, Technikerstrasse 25, A-6020 Innsbruck, Austria \\ ${ }^{2}$ Department of Biology, University of Leiden, Gorlaeus Laboratoria, POB 9502, 2300-RA Leiden, The Netherlands \\ ${ }^{3}$ Department of Biochemistry, University of Bologna, Via Tolara di Sopra 50, I-40064 Ozzano Emilia Bologna, Italy \\ ${ }^{4}$ Netherlands Institute of Ecology, Centre for Estuarine and Coastal Ecology, Vierstraat 28, 4401-EA Yerseke, The Netherlands
}

\begin{abstract}
Eutrophication of the Northern Adriatic Sea results in regular and long periods of hypoxia and occasional anoxia. Thus, animals living in this area must be well adapted to these conditions, including sole Solea solea, a flatfish living on sandy bottoms. Healthy sole were kept in aquaria at $20^{\circ} \mathrm{C}$ for at least $2 \mathrm{mo}$. The fish were exposed to hypoxia after a preacclimation period of $30 \mathrm{~h}$ at normoxia. During normoxia oxygen levels were kept constant at $80 \%$ air saturation, during hypoxia they were set at $60,40,20,12$ or $6 \%$ air saturation. Control experiments were carried out at $100 \%$ air saturation. After conditioning the fish were anaesthetized and blood, muscle and liver samples taken. In the extracts of freeze-clamped tissues, 12 components of energy metabolism were measured in muscle, 11 in liver. Between 100 and $20 \%$ air saturation no major changes in metabolite concentration were found, while at 12 and $6 \%$ important changes were observed. Lactate levels increased in all tissues, particularly in blood, where, unexpectedly for flatfish, high concentrations were found (up to $19.8 \mathrm{mM}$ ). ATP declined in liver and blood, but not in muscle where the decrease in phosphocreatine appeared to be sufficient in stabilizing the ATP level. Total anaerobic energy production, calculated from changes in metabolite concentrations, amounted to 52 and $148 \mu \mathrm{mol}$ ATP $100 \mathrm{~g}^{-1} \mathrm{~h}^{-1}$ at 12 and $6 \%$ air saturation, respectively. At these oxygen levels total metabolism was depressed by 27 and $48 \%$, indicating that metabolic depression is a more effective survival strategy than the induction of anaerobic metabolism.
\end{abstract}

KEY WORDS: Anaerobiosis · Hypoxia - Lactate - Metabolic depression - Solea Solea

\section{INTRODUCTION}

Fish exposed to reduced levels of environmental oxygen respond both with energy saving strategies and with attempts to increase the supply of oxygen to the tissues. Depending on the severity of hypoxia and its duration, these strategies may imply changes at the behavioural, physiological and tissue level. (1) Behavioural strategies are mainly applied to reduce energy demand by lowering locomotor activity or by moving to areas of lower temperature (Schurmann et al. 1991,

\footnotetext{
- Dedicated to Prof. W. Wieser on the occasion of his 70th birthday
}

Wood 1991, Wood \& Malvin 1992, Nilsson et al. 1993). Within these immediately effective processes, shifts from water breathing to surface and/or air breathing (Johansen 1970, Kramer \& McClure 1982, Peterson 1990 ) are also of great importance in improving survival at low oxygen tensions. (2) Physiological strategies comprise increases in gill diffusing capacity and in the number of perfused gill lamellae (Randall \& Daxboeck 1984); changes in erythrocytic adenylate concentrations (Weber 1982); changes in ventilation volume, particularly in the ventilatory stroke volume (Glass 1992); changes in enzyme activities (Greaney et al. 1980, Van den Thillart \& Smit 1984, Storey 1988); and metabolic depression (Hochachka \& Guppy 1987. 
Nilsson \& Lutz 1993). (3) Responses on the tissue level include systemic alterations such as changes in mitochondrial densities in muscle (Weber 1982), increased erythropoiesis (Nikinmaa 1990) or increases in hematocrit due to the splenic release of red blood cells (Nilsson 1983).

Because of their form and lifestyle, flatfish do not have the option of evasive reactions, hypoxia usually occurring over vast areas, too large for the fish to cover. Respiratory adaptations are well documented for trout and carp (Jones et al. 1970). Although improved efficiency of oxygen transport requires the coupling of ventilatory and circulatory flows, the major effect comes from an increased water flow over the gills, which also causes an increase in energy consumption. Despite an improved oxygen extraction capacity, the maximal oxygen uptake rate always decreases at lower oxygen levels, thus narrowing the scope for activity. Suppression of the activity rate of metabolism is, therefore, an obligate survival strategy in many hypoxia/anoxia-adapted animals (Nilsson \& Lutz 1993). By reducing their metabolic rate during hypoxia, animals delay the depletion of glycogen stores as well as the accumulation of toxic levels of lactate. For example, in anoxic turtle (Jackson 1968) and goldfish (Van Waversveld et al. 1989) heat production falls to 20 to $30 \%$ of the standard metabolic rate.

Hypoxic conditions can be tolerated by many fish species. Sole Solea solea was chosen for the present study because of its stationary behaviour and low migration speed. It moves only a few hundred metres in $24 \mathrm{~h}$, with a maximum of about $1.5 \mathrm{~km}$ at high temperatures (Lagardère et al. 1988, Sureau \& Lagardère 1991). Since hypoxic bottom layers may extend for up to $900 \mathrm{~km}^{2}$ in the Adriatic Sea (Rinaldi et al. 1993), sole are bound to experience hypoxic conditions in such an environment.

In a previous paper we described the oxygen consumption patterns of Solea solea before and during a $12 \mathrm{~h}$ exposure to different hypoxia levels (Van den Thillart et al. 1994). Below $20 \%$ air saturation both resting and active rate of oxygen consumption were depressed. In this paper the key metabolites for energy metabolism in muscle, liver and blood from the same fish were investigated in order to present a biochemical basis for this phenomenon and to investigate the effect of slight, moderate and severe hypoxia on the intermediate metabolism of sole.

\section{MATERIAL AND METHODS}

Animals and conditioning. Sole were obtained from local fishermen at the fishing harbor of Cesenatico (Italy) and kept for 2 to 4 mo in seawater aquaria with percolated sand beds acting as substrate and filter at the Centro di Ricerche Marine, Cesenatico. From April to September fish were kept at $20 \pm 1{ }^{\circ} \mathrm{C}$ within a salinity range of 24 to $37 \mathrm{ppt}$ and exposed to a natural diurnal light cycle (for more details see Van den Thillart et al. 1994). Animals fed daily with live polychaetes (Nereis sp., 1 to $2 \mathrm{~cm}$ pieces) stayed in good condition for several months in the aquaria. Experiments were carried out in September on a fixed daily protocol to expose all animals to an identical diurnal cycle (Van den Thillart \& Dalla Via 1993). This is important since sole show a circadian rhythm with the main locomotor activity at night (Kruuk 1963, Sureau \& Lagardère 1991). Immature sole with a mean weight of $75.6 \pm 21.0 \mathrm{~g}$ and a mean total length of 19.3 $\pm 1.8 \mathrm{~cm}$ were used in the experiments.

Exposure to hypoxia was carried out in a flowthrough respirometer where constant oxygen levels were maintained (Van den Thillart \& Verbeek 1991). Animals were starved for $2 \mathrm{~d}$ prior to the experiments and acclimated in the respirometer chamber for approximately $30 \mathrm{~h}$ under control conditions $\left(20^{\circ} \mathrm{C}\right.$, 30 to 32 ppt salinity, normoxia). Experiments were carried out at $60 \%(12.4 \mathrm{kPa}, 93.3$ Torr $), 40 \%(8.3 \mathrm{kPa}$ ), $20 \%(4.1 \mathrm{kPa}), 12 \%(2.5 \mathrm{kPa})$ and $6 \%(1.2 \mathrm{kPa})$ air saturation, exposures always lasting for $12 \mathrm{~h}(21: 00$ to $09: 00 \mathrm{~h})$. At the end of the hypoxia period the fish were anaesthetized with MS222 (3-aminobenzoic-acid ethyl-ester methanesulfonate salt, Sigma, St. Louis, USA) to reduce stress effects due to handling. The anaesthetic was injected slowly into the respirometer to expose the fish to a final concentration of $85 \mathrm{mg} \mathrm{l}^{-1}$ for $10 \mathrm{~min}$.

In preliminary experiments we had found that lower MS222 concentrations ( 70 and $80 \mathrm{mg} \mathrm{l}^{-1}$ ) did not sufficiently reduce locomotor activity, whereas MS222 concentrations higher than $85 \mathrm{mg} \mathrm{l}^{-1}$ (90 and $100 \mathrm{mg} \mathrm{l}^{-1}$ ) reduced opercular and respiratory activity, resulting in tissue hypoxia. Moreover, MS222 concentrations higher than $85 \mathrm{mg}^{-1}$ induced a strong escaping behaviour and heavy convulsions over the whole body at the beginning of anaesthesia, stimulating pronounced undulation of the dorsal and ventral fins during exposure.

Sampling. Anaesthetized fish were taken out of the respirometer chamber and a tissue block of approximately $20 \times 20 \times 2 \mathrm{~mm}$ of the epaxial white muscle was immediately freeze-clamped with aluminum tongs precooled in liquid nitrogen. Blood samples were obtained by severing the caudal fin: the incision was rapidly blotted and blood from the caudal artery was drawn into a heparinized syringe. Liver was collected after dissection and freeze-clamped. The sampling procedure lasted 5 to $10 \mathrm{~s}$ for muscle tissue, 30 to $60 \mathrm{~s}$ for blood and 60 to $90 \mathrm{~s}$ for the liver. Blood samples 
were immediately analyzed, while the freeze-clamped muscle and liver samples were stored in liquid nitrogen until analysis.

Metabolite extraction. Blood samples were injected into $0.5 \mathrm{ml}$ ice-cold $6 \%$ perchloric acid (PCA) with $4 \mathrm{mM} \mathrm{NaF}$ and $4 \mathrm{mM}$ EDTA, homogenized with a sonicator (Soniprep 150-HSE Scientific Instrumentations) for 1 to $2 \mathrm{~min}$ and centrifuged at $15000 \times \mathrm{g}$ for $20 \mathrm{~min}$ in a cooled centrifuge (Sigma 220). The supernatant was carefully adjusted with $2 \mathrm{M} \mathrm{K}_{2} \mathrm{CO}_{3}$ in $100 \mathrm{mM}$ $\mathrm{K}_{2} \mathrm{HPO}_{4}$ to $\mathrm{pH} 6$ to 7 . The sample remained on ice for $30 \mathrm{~min}$ and was then centrifuged for $20 \mathrm{~min}$ at $15000 \times$ $g$. The obtained supernatant was used immediately for measurement of metabolites. Adenosine-5'-triphosphate (ATP), glucose-6-phosphate (G6P) and glucose1 -phosphate (G1P) in blood extracts are intraerythrocytic metabolites, so their concentration must be related to the number of blood cells. Since erythrocyte volume increases under hypoxic conditions (Nikinmaa 1986), hematocrit values increase without relation to spleen contraction and/or erythropoiesis. Thus we chose to take the blood sediment after homogenization and the first centrifugation step as a reference, also in view of the difficulties in obtaining hematocrit samples for all specimens. The sediment was dried in an oven (at $60^{\circ} \mathrm{C}$ ) and the dry weight determined for each blood sample.

The freeze-clamped muscle slice was weighed and crushed in a stainless steel beaker, precooled with liquid nitrogen. The 2 skin layers were removed by striking the tissue slice with an iron pestle, muscle fibers being crushed and skin layers remaining intact. The mixture of liquid nitrogen and muscle fibers was transferred to a precooled mortar mill (Retsch, Germany) where the tissue was pulverized under liquid nitrogen after addition of 5 volumes of extraction medium (Dalla Via \& Lackner 1991). The extraction medium consisted of 15\% PCA and 5\% ortho-phosphoric acid. The obtained powder was thawed in an alcohol bath at -8 to $-10^{\circ} \mathrm{C}$ to avoid degradation of phosphorylated compounds which proceeds faster between 0 and $-5^{\circ} \mathrm{C}$ than at room temperature (Bito \& Amano 1962, Nowlan \& Dyer 1974).

The thawed homogenate was mixed well and left on ice for $30 \mathrm{~min}$ before centrifugation at $26600 \times g$ for $20 \mathrm{~min}$ (refrigerated Sorvall RC2-B, SS34). The supernatant was adjusted to $\mathrm{pH} 6.7$ to 6.9 with $5 \mathrm{M} \mathrm{K}_{2} \mathrm{CO}_{3}$. centrifuged again after a precipitation time of $30 \mathrm{~min}$, and its volume was determined by weight and corrected for density differ- ence. The obtained supernatant was immediately used for enzymatic determination of metabolites.

The freeze-clamped liver was treated in an analogous way, starting from pulverizing it under liquid nitrogen in the mortar mill.

Analysis. Glycolytic intermediates were measured enzymatically by determining the changes in absorbance of nicotinamide coenzyme at $340 \mathrm{~nm}$ as described in Bergmeyer $(1984,1985 \mathrm{a}, \mathrm{b})$ and in Dalla Via et al. (1989).

Statistics. Statistical analysis was performed by CSS (Complete Statistical Systems, Statsoft, Inc, release 3.1). Different hypoxic conditions were compared to normoxic ones using the Mann-Whitney $U$-test.

\section{RESULTS}

Hypoxia-dependent changes of individual metabolites were investigated in blood, liver and muscle.

Blood. The concentration of lactate started rising at $20 \%$ air saturation and had increased 2.7 -fold, at $12 \%$ saturation the increase was 16.9 -fold, and at $6 \% 76.3-$ fold as compared with the resting value of $0.26 \mu \mathrm{mol}$ $\mathrm{ml}^{-1}$ (Fig. 1). Glucose concentration was significantly higher at 40 and $20 \%$ air saturation than under normoxia, but at lower oxygen levels 2 groups of fish could be distinguished: about $50 \%$ of the animals showed no significant changes, whereas the others

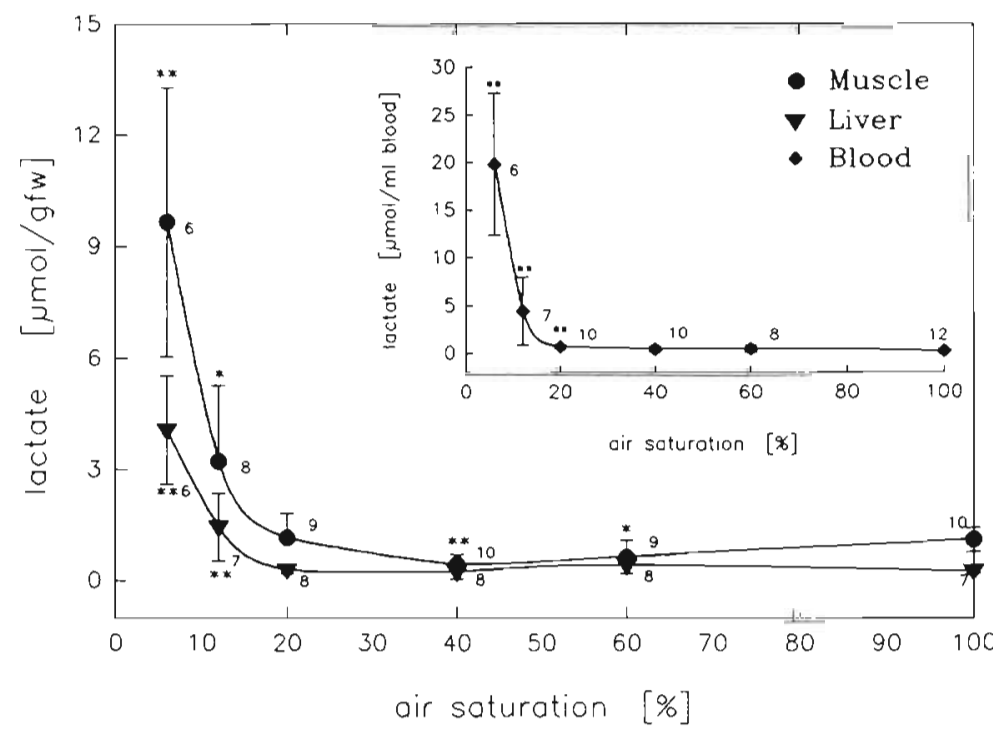

Fig. 1. Solea solea. Lactate levels in muscle, liver and blood after a $12 \mathrm{~h}$ exposure to hypoxia $(6,12,20,40,60$ and $100 \%$ air saturation). Fish were preacclimated for $2 \mathrm{~d}$ in a respirometer at $80 \%$ (or $100 \%$ for control) air saturation. A significant difference from the control group (100\%) is indicated by asterisks $(* p<0.05 ; \cdots p<0.01)$. Mean, SD and no. of observations are indicated for each condition; gfw: $g$ fresh weight 


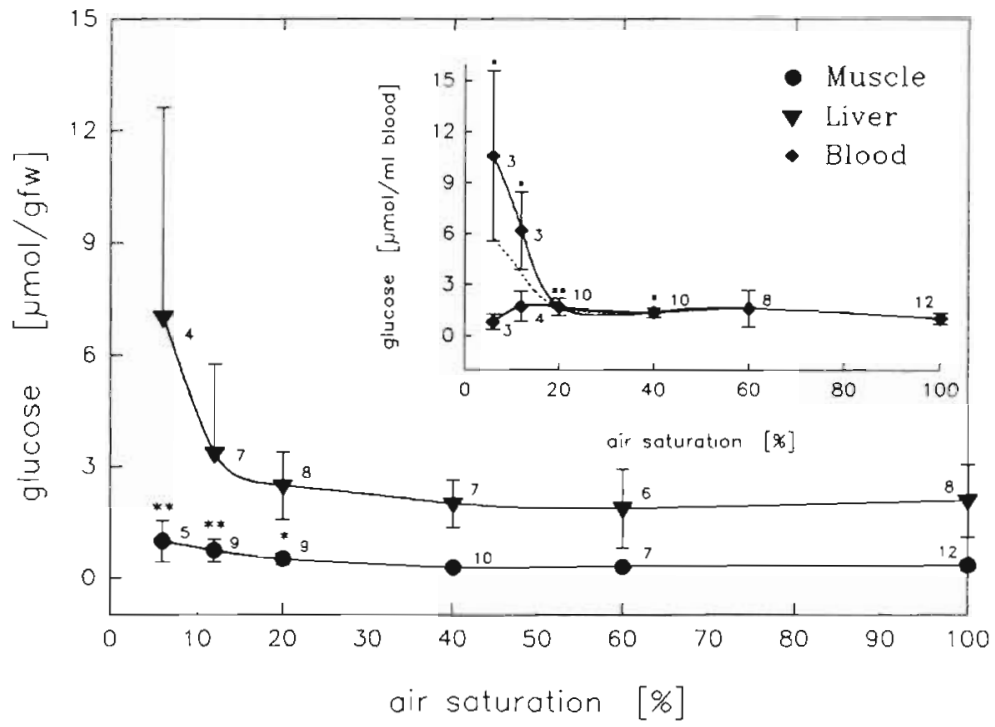

Fig. 2. Solea solea. Glucose levels in muscle, liver and blood after a 12 h exposure to hypoxia (for details see Fig. 1). Hyperglycemia occurred in $50 \%$ of the animals. Solid lines: averages of the hyperglycemic and the normoglycemic group of fish, respectively; dashed line: the mean

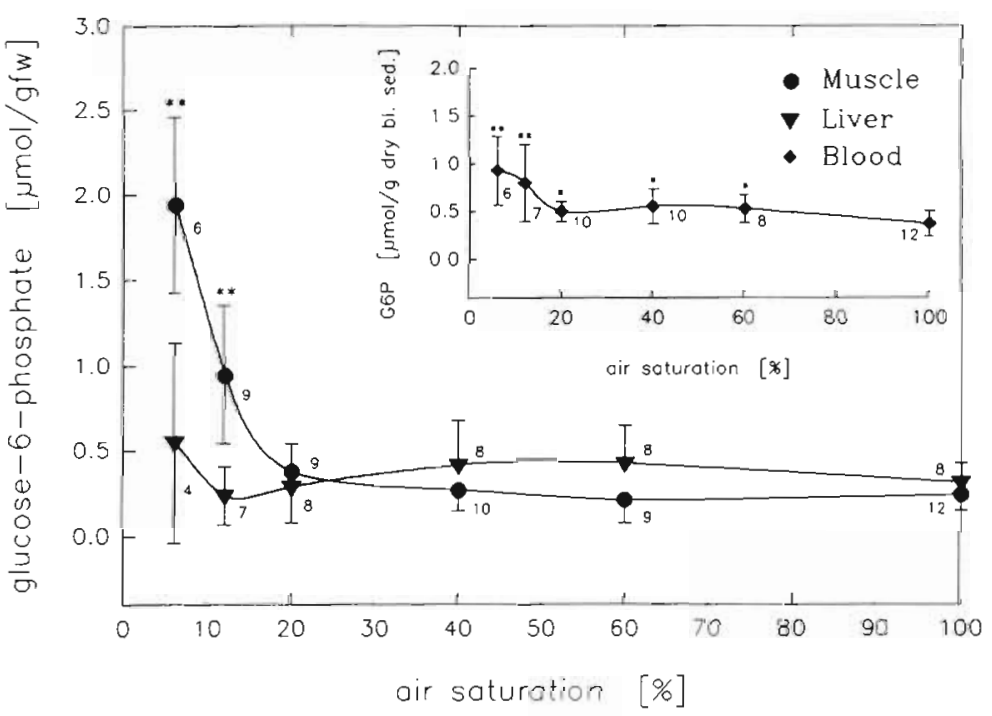

Fig. 3. Solea solea. Glucose-6-phosphate levels in muscle, liver and erythrocytes after a 12 h exposure to hypoxia (for details see Fig. 1). Concentrations in blood are given as dry blood sediment (dry bl. sed.) as a reference for blood cell mass tration decreased to $48 \%$ of the normoxic value. A significant increase of blood sediment was observed under severe hypoxic conditions, strongly indicating a numerical increase of blood cells (Fig. 6).

Liver. At $6 \%$ air saturation liver lactate concentration rose 16.2-fold from the normoxic value of $0.25 \mu \mathrm{mol} \mathrm{g}^{-1}$ fresh wt (Fig. 1). Glucose concentration showed a tendency to increase in this range, albeit not significantly (Fig. 2). G6P and G1P concentrations did not change significantly over the entire exposure range (Figs. 3 \& 4), whereas ATP decreased significantly to $33.5 \%$ of the normoxic value, the decrease commencing at 20\% air saturation (Fig. 5). Glycerol-3-phosphate rose significantly at $6 \%$ saturation (Table 1). Various other metabolites of intermediary metabolism did not display significant concentration changes in the liver: fructose-6-phosphate (F6P), pyruvate, 2-oxoglutarate, malate and ammonia (Table 1). Although rising with increasing hypoxia the lactate-pyruvate ratio was not significantly different from the normoxic value at any of the levels of hypoxia.

Muscle. At slight hypoxia a small drop in lactate concentration was observed. Under severe hypoxia lactate rose 8.8 -fold (Fig. 1). Glucose was significantly increased at $20 \%$ air saturation and reached 2.8 times its control value at $6 \%$ (Fig. 2). A highly significant increase was also observed for G6P and G1P at 6 and $12 \%$ air saturation, respectively (Figs. 3 \& 4). Muscle ATP concentration did not change significantly (Fig. 5). The phosphocreatine pool (PCr) was reduced to approximately $56 \%$ at $6 \%$ air saturation (Fig. 7), whereas pyruvate and malate increased slightly under severe hypoxia. Fructose, 2-oxoglutarate and ammonia concentrations remained unaltered. The lactate/pyruvate ratio was significantly increased at $6 \%$ air saturation (Table 2).

\section{DISCUSSION}

\section{Responses to hypoxia} increased continuously starting at hypoxic levels of $60 \%$ air saturation (Fig. 3), whereas G1P concentration remained unaltered over the entire hypoxic range (Fig. 4). As depicted in Fig 5 blood ATP concentration showed a highly significant decrease at air saturation of $20 \%$ and below. At $6 \%$ air saturation ATP concen-
On the basis of metabolic responses 3 hypoxic ranges can be distinguished: (1) slight hypoxia between normoxia and $40 \%$ air saturation without major effects on intermediate metabolism, (2) moder- 
ate hypoxia between 40 and $20 \%$ air saturation with slight to transient metabolic disturbances, and (3) severe hypoxia below $20 \%$ air saturation with severe to lethal metabolic perturbation

During slight hypoxia the first metabolic effects appeared in the blood, where G6P rose significantly at $60 \%$ air saturation. No other major changes in metabolite concentrations occurred except for lactate in the muscle, where at 60 and $40 \%$ air saturation concentrations dropped to 59 and $41 \%$ of the normoxic values, respectively (Fig. 1). This suggests reduction of routine locomotor activity. Flatfish are not able to sustain long aerobic activity and show increased lactate levels at all swimming speeds (Duthie 1982). This is also in agreement with our findings reported in the preceding paper (Van den Thillart et al. 1994) which showed that the first behavioural strategy of sole under moderate and slight hypoxia was the reduction of active metabolic rate.

Moderate hypoxia was characterized by the onset of physiological defense strategies. Glucose concentration in blood (at 40 and $20 \%$ air saturation) and muscle (at $20 \%$ air saturation) was significantly higher than under normoxia, indicating catecholamine-mediated glycogenolysis (Wright et al. 1989) (Fig. 2). The transitional character of moderate hypoxia was evident from the significant drop in ATP concentration in blood and liver at $20 \%$ air saturation (Fig. 5). Intraerythrocytic organophosphates are known to be strong modulators of hemoglobin-oxygen affinity. binding directly to the pigment and changing the tertiary or quaternary structure of the protein (Nikinmaa 1990). A decrease of ATP concentration is known to cause $\mathrm{H}^{+}$ efflux followed by an increase in intracellular $\mathrm{pH}$ which is partly responsible for the increased $\mathrm{O}_{2}$ affinity via the Bohr effect (Greaney \& Powers 1977. Greaney et al. 1980, Wood 1980, Burggren et al. 1991).

Severe hypoxia at 12 and $6 \%$ air saturation was characterized by activation of anaerobic metabolism leading to an increase of lactate concentration in all tissues (Fig. 1). However, lactate levels were much higher in blood than in muscle, which was not expected and will be discussed separately.

Blood glucose increased significantly only in about $50 \%$ of the fish under severe hypoxia, whereas in the other $50 \%$ or so it remained almost unchanged.

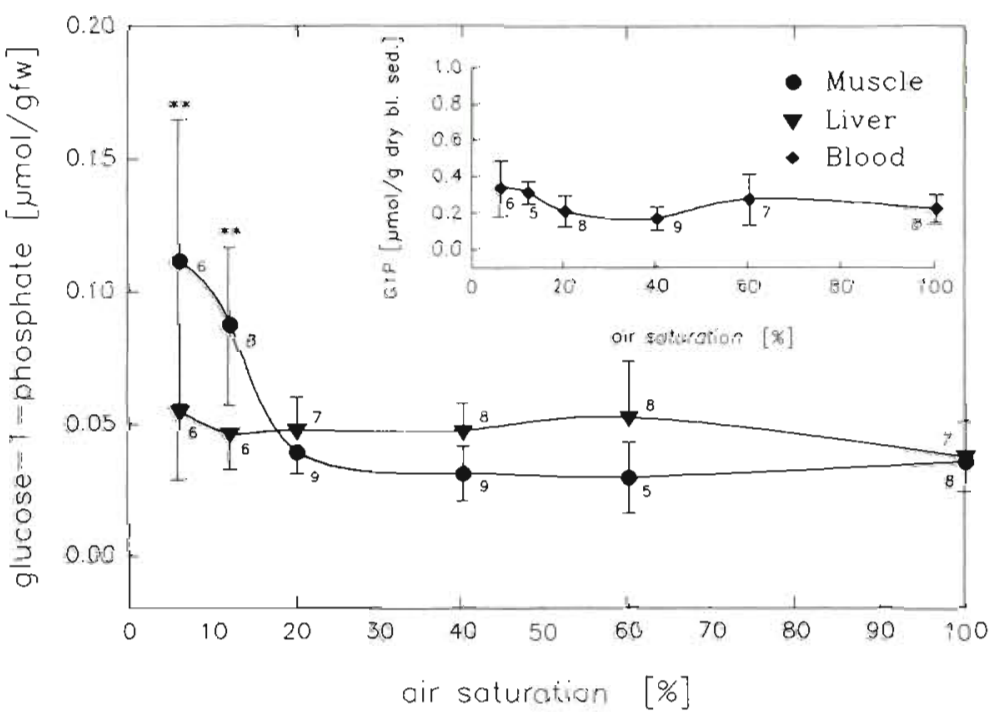

Fig. 4. Solea solea. Glucose-1-phosphate levels in muscle, liver and erythrocytes after a 12 h exposure to hypoxia (for details see Figs. 1 \& 3 )

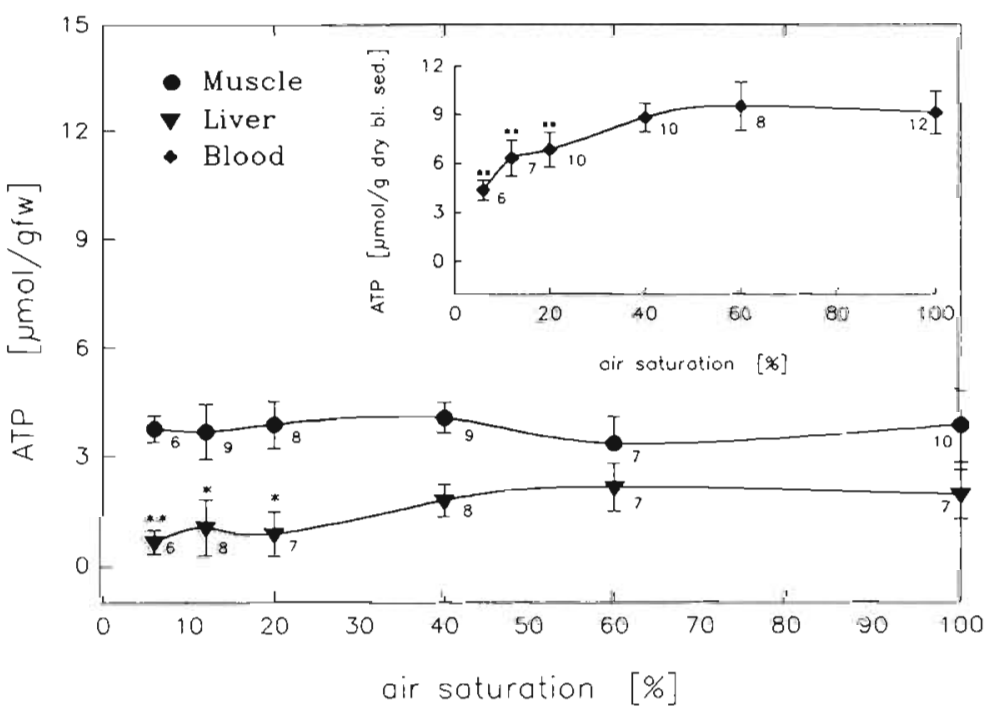

Fig. 5. Solea solea. ATP levels in muscle, liver and erythrocytes after a $12 \mathrm{~h}$ exposure to hypoxia (for details see Figs. 1 \& 3)

Glycogenolysis in hepatocytes appears to be stimulated by adrenaline and/or noradrenaline. Release of catecholamines is typically stress related and may discontinue under prolonged hypoxia. In consequence this may also hold for liver glycogenolysis and hyperglycemia. Recently a similar response in canulated trout exposed to hypoxia was observed (Van Raay \& Van den Thillart unpubl.): $50 \%$ of the trout exposed to hypoxia showed hyperglycemia coupled with extremely high catecholamine levels, whilst no hyperglycemia was observed in the other $50 \%$ with only a moderate increase of catecholamines. In sole the liver 


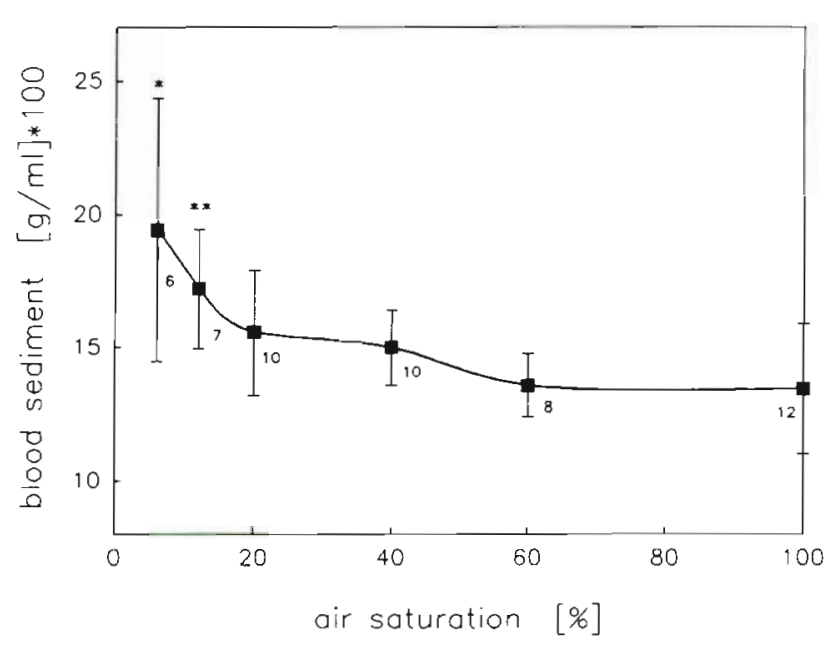

Fig. 6. Solea solea. Blood sediment expressed in $\%$ as dry blood sediment $\mathrm{ml}^{-1}$ blood $\left(\mathrm{g} \times 100 \mathrm{ml}^{-1}\right)$. Blood sediment obtained after the first centrifugation (see 'Methods') is an indicator of cell biomass in the blood

cannot be an important glycogen store since it accounts for only $0.6 \%$ of total body mass. In the anoxia-tolerant crucian carp, on the other hand, the liver constitutes 10 to $15 \%$ of body mass, glycogen accounting for 25 to $27 \%$ of liver mass (Hyvärinen et al. 1985, Nilsson 1990). Thus in crucian carp liver glycogen represents up to $4 \%$, muscle glycogen only 1 to $2 \%$, of body mass: this may be an important prerequisite in this species of fish for maintaining glycolytic energy production during prolonged periods of hypoxia.
In muscle we found no change in ATP, the $44 \%$ decrease of phosphocreatine driving the regeneration of the ATP pool. The constancy of the ATP level in this important glycolytic tissue may play a part in stabilizing the rate of glycolysis. Since ATP is an important inhibitor of phosphofructokinase (PFK) a lower ATP and higher AMP level in muscle would have increased PFK activity and glycolytic flow. Thus lower muscle lactate levels should be expected in sole, where lactate concentrations indeed rose only to $9.6 \mu \mathrm{mol} \mathrm{g}^{-1}$ under severe hypoxia, whereas in plaice, after exhausting exercise, muscle lactate levels between 30 and $50 \mu \mathrm{mol} \mathrm{g}^{-1}$ were found (Wardle 1978).

In both liver and erythrocytes, ATP levels decreased at $20 \%$ air saturation, indicating an improvement of oxygen affinity. It is known that in fish hypoxic exposure induces a decrease in the erythrocytic nucleoside triphosphate concentration (Nikinmaa 1990), even within $1 \mathrm{~h}$ of acute exposure to severe hypoxia (35 mm $\mathrm{Hg}$ in trout; Tetens \& Lykkeboe 1985). The significant increase in blood sediment (Fig. 6) indicates a gain in blood $\mathrm{O}_{2}$ capacity resulting from an increase in blood cells derived from hypoxia-stimulated erythropoiesis (Härdig et al. 1978, McLeod et al. 1978), or enhanced release of red blood cells from the spleen (Nilsson 1983)

\section{The flatfish paradox of lactate distribution}

It was discovered by Wardle (1978) that, in contrast to other fish, Pleuronectes platessa retained lactate in

Table 1. Solea solea. Metabolite concentrations in the liver after a $12 \mathrm{~h}$ exposure to different oxygen levels. Fish were preacclimated for $2 \mathrm{~d}$ in a respirometer at $80 \%$ (or $100 \%$ for controls) air saturation. Significant difference from the normoxic control group is marked by an asterisk $(" \mathrm{p}<0.05)$. Values are expressed in $\mu \mathrm{mol} \mathrm{g}^{-1}$ fresh wt. Means \pm SD are given; numbers of observations in parentheses

\begin{tabular}{|c|c|c|c|c|c|c|}
\hline$\%$ air saturation: & $100 \%$ & $60 \%$ & $40 \%$ & $20 \%$ & $12 \%$ & $6 \%$ \\
\hline Fructose-6-phosphate & $\begin{array}{c}0.067 \\
\pm 0.033(7)\end{array}$ & $\begin{array}{c}0.103 \\
\pm 0.078(7)\end{array}$ & $\begin{array}{c}0.100 \\
\pm 0.054(8)\end{array}$ & $\begin{array}{c}0.067 \\
\pm 0.043(7)\end{array}$ & $\begin{array}{c}0.087 \\
\pm 0.043(6)\end{array}$ & 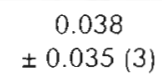 \\
\hline Pyruvate & $\begin{array}{c}0.036 \\
\pm 0.037(4)\end{array}$ & $\begin{array}{c}0.070 \\
\pm 0.061(4)\end{array}$ & $\begin{array}{c}0.069 \\
\pm 0.035(3)\end{array}$ & $\begin{array}{c}0.018 \\
\pm 0.013(6)\end{array}$ & $\begin{array}{c}0.058 \\
\pm 0.044(5)\end{array}$ & $\begin{array}{c}0.052 \\
\pm 0.037(3)\end{array}$ \\
\hline 2-oxoglutarate & $\begin{array}{c}0.100 \\
\pm 0.075(7)\end{array}$ & $\begin{array}{c}0.101 \\
\pm 0.052(7)\end{array}$ & $\begin{array}{c}0.152 \\
\pm 0.105(8)\end{array}$ & $\begin{array}{c}0.134 \\
\pm 0.043(8)\end{array}$ & $\begin{array}{c}0.178^{\circ} \\
\pm 0.066(8)\end{array}$ & $\begin{array}{c}0.099 \\
\pm 0.057(6)\end{array}$ \\
\hline Malate & $\begin{array}{c}0.329 \\
\pm 0.248(6)\end{array}$ & $\begin{array}{c}0.401 \\
\pm 0.221(7)\end{array}$ & $\begin{array}{c}0.326 \\
\pm 0.129(8)\end{array}$ & $\begin{array}{c}0.617^{\circ} \\
\pm 0.141(7)\end{array}$ & $\begin{array}{c}0.542 \\
\pm 0.264(7)\end{array}$ & $\begin{array}{c}0.400 \\
\pm 0.208(6)\end{array}$ \\
\hline Ammonia & $\begin{aligned} & 1.099 \\
\pm & 0.424(7)\end{aligned}$ & $\begin{array}{c}1.088 \\
\pm 0.675(7)\end{array}$ & 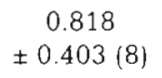 & $\begin{array}{c}1.244 \\
\pm 0.774(8)\end{array}$ & $\begin{array}{c}1.179 \\
\pm 0.465(8)\end{array}$ & $\begin{array}{c}0.862 \\
\pm 0.387(6)\end{array}$ \\
\hline Glycerol-3-phosphate & $\begin{array}{c}0.218 \\
\pm 0.182(6)\end{array}$ & $\begin{array}{c}0.254 \\
\pm 0.108(7)\end{array}$ & $\begin{array}{c}0.224 \\
\pm 0.155(6)\end{array}$ & $\begin{array}{c}0.272 \\
\pm 0.204(8)\end{array}$ & $\begin{array}{c}0.423 \\
\pm 0.238(8)\end{array}$ & $\begin{array}{c}0.673^{\circ} \\
\pm 0.275(6)\end{array}$ \\
\hline Lactate/pyruvate ratio & $\begin{array}{c}13.417 \\
\pm 9.962(4)\end{array}$ & $\begin{array}{c}7.712 \\
\pm 5.983(4)\end{array}$ & $\begin{array}{c}7.544 \\
+4.302(3)\end{array}$ & $\begin{aligned} & 23.459 \\
\pm & 15.105(6)\end{aligned}$ & $\begin{aligned} & 33.625 \\
\pm & 21.762(5)\end{aligned}$ & $\begin{aligned} & 83.349 \\
\pm & 53.867(3)\end{aligned}$ \\
\hline
\end{tabular}


the muscle tissue after forced exercise. Between 30 and $50 \mu \mathrm{mol} \mathrm{g}{ }^{-1}$ were found in muscle, whereas blood lactate concentrations rarely rose above $2 \mu \mathrm{mol} \mathrm{ml}^{-1}$ (Wardle 1978, Batty \& Wardle 1979). In other benthic flatfish species, flathead sole Hippoglossoides elassodon (Turner et al. 1983) and starry flounder Platichthys stellatus (Wood et al. 1977. Milligan \& Wood 1987, Milligan \& McDonald 1988), blood lactate levels remained low too, despite high muscle lactate concentrations. The same lactate pattern was found in winter flounder Pseudopleuronectes americanus where after strenuous exercise the lactate in the white muscle was 30 times higher than in the blood. Infusion of ${ }^{14} \mathrm{C}$-labeled lactate supported the idea of an active inward transport mechanism for lactate in flounder muscle (Girard \& Milligan 1992). In contrast, the blood lactate concentra-

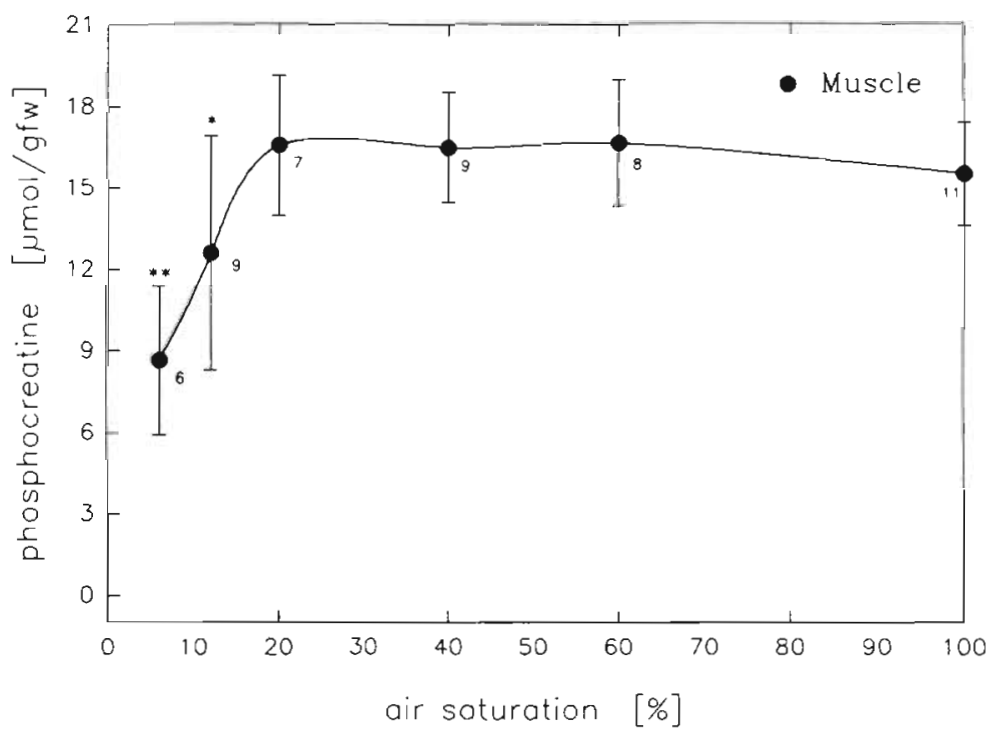

Fig. 7. Solea solea. Phosphocreatine levels in muscle after a $12 \mathrm{~h}$ exposure to hypoxia (for details see Fig. 1) tions in this study on Solea solea were about twice as high as those in muscle. Our investigation differed from the previously mentioned ones by the treatment of the fish. We used chronic hypoxic exposure, whereas in the other investigations the fish were stimulated to exhausting burst activity. Stimulation by catecholamines was considered responsible for the retention of lactate in the muscle cells of flatfish (Wardle 1978). The release of catecholamines is believed to be due to the decline in blood $\mathrm{O}_{2}$ content, rather than to acidosis. Catecholamines do not rise substantially until the degree of stress becomes very

severe (Randall \& Perry 1992). Strenuous and exhausting exercise can always be considered severe stress, so catecholamines can be expected to be released within minutes, reaching high values in the arterial plasma (Wood et al. 1990). The retention of lactate within the muscle cell makes sense since its oxidation occurs mainly there. The severity of stress due to hypoxia may depend on various factors, on the hypoxic level itself, on how fast it is reached as well as on how long it persists. Although data from published literature are confusing on this subject, there is

Table 2. Solea solea. Metabolite concentrations in muscle after a $12 \mathrm{~h}$ exposure to different oxygen levels. Fish were preacclimated for $2 \mathrm{~d}$ in a respirometer at $80 \%$ (or $100 \%$ for controls) air saturation. Significant difference from the normoxic control group is marked by asterisks ( $\mathrm{p}<0.05 ; \cdots \mathrm{p}<0.01$ ). Values are expressed in $\mu \mathrm{mol} \mathrm{g}^{-1}$ fresh wt. Means $\pm \mathrm{SD}$ are given; numbers of observations in parentheses

\begin{tabular}{|c|c|c|c|c|c|c|}
\hline$\%$ air saturation: & $100 \%$ & $60 \%$ & $40 \%$ & $20 \%$ & $12 \%$ & $6 \%$ \\
\hline Fructose & $\begin{array}{c}0.039 \\
\pm 0.038(6)\end{array}$ & $\begin{array}{c}0.051 \\
\pm 0.034(5)\end{array}$ & $\begin{array}{c}0.041 \\
\pm 0.030(6)\end{array}$ & $\begin{array}{c}0.040 \\
\pm 0.023(7)\end{array}$ & $\begin{array}{c}0.054 \\
\pm 0.034(8)\end{array}$ & $\begin{array}{c}0.116 \\
\pm 0.060(4)\end{array}$ \\
\hline Fructose-6-phosphate & $\begin{array}{c}0.062 \\
\pm 0.022(12)\end{array}$ & $\begin{array}{c}0.050 \\
\pm 0.024(8)\end{array}$ & $\begin{array}{c}0.058 \\
\pm 0.025(9)\end{array}$ & $\begin{array}{c}0.085^{\circ} \\
\pm 0.020(8)\end{array}$ & $\begin{array}{r}0.185 \cdots \\
\pm 0.098(9)\end{array}$ & $\begin{array}{r}0.355 \cdots \\
\pm 0.131(6)\end{array}$ \\
\hline Pyruvate & $\begin{array}{c}0.021 \\
\pm 0.008(7)\end{array}$ & $\begin{array}{c}0.014 \\
\pm 0.006(6)\end{array}$ & $\begin{array}{c}0.022 \\
\pm 0.009(8)\end{array}$ & $\begin{array}{c}0.025 \\
+0.015(8\}\end{array}$ & $\begin{array}{c}0.043^{\circ} \\
\pm 0.019(9)\end{array}$ & $\begin{array}{c}0.036^{\circ} \\
\pm 0.016(6)\end{array}$ \\
\hline 2-oxoglutarate & $\begin{array}{c}0.012 \\
\pm 0.007(10)\end{array}$ & $\begin{array}{c}0.019 \\
\pm 0.010(4)\end{array}$ & $\begin{array}{c}0.019 \\
\pm 0.013(8)\end{array}$ & $\begin{array}{c}0.009 \\
\pm 0.005(6)\end{array}$ & $\begin{array}{c}0.014 \\
\pm 0.007(8)\end{array}$ & $\begin{array}{c}0.007 \\
\pm 0.004(5)\end{array}$ \\
\hline Malate & $\begin{array}{c}0.051 \\
\pm 0.013(11)\end{array}$ & $\begin{array}{c}0.041 \\
\pm 0.014(6)\end{array}$ & $\begin{array}{c}0.039^{\circ} \\
\pm 0.016(10)\end{array}$ & $\begin{array}{c}0.068 \\
\pm 0.055(9)\end{array}$ & $\begin{array}{c}0.063 \\
\pm 0.029(9)\end{array}$ & $\begin{array}{c}0.100^{\circ} \\
\pm 0.047(6)\end{array}$ \\
\hline Ammonia & $\begin{array}{c}0.301 \\
\pm 0.233(10)\end{array}$ & $\begin{array}{c}0.446 \\
\pm 0.256(6)\end{array}$ & $\begin{array}{c}0.356 \\
\pm 0.210(8)\end{array}$ & $\begin{array}{c}0.364 \\
\pm 0.163(8)\end{array}$ & $\begin{array}{c}0.224 \\
\pm 0.184(7)\end{array}$ & $\begin{array}{c}0.202 \\
\pm 0.167(4)\end{array}$ \\
\hline Lactate/pyruvate ratio & $\begin{array}{c}51.015 \\
\pm 26.849(5)\end{array}$ & $\begin{array}{c}42.555 \\
\pm 20.119(6)\end{array}$ & $\begin{array}{c}21.015 \\
\pm 13.774(8)\end{array}$ & $\begin{array}{c}54.379 \\
\pm 15.572(8)\end{array}$ & $\begin{array}{c}79.744 \\
\pm 31.328(8)\end{array}$ & $\begin{array}{c}286.754^{\circ} \\
\pm 101.377(6)\end{array}$ \\
\hline
\end{tabular}


Table 3. Solea solea. Anaerobic energy production of sole exposed to $12 \mathrm{~h}$ of hypoxia at 6 and $12 \%$ air saturation. ATP equivalents for a standard whole fish of $100 \mathrm{~g}$ are calculated based on the following relative tissue mass: liver $0.63 \%$, muscle $65 \%$, blood $8 \%$, rest $15 \%$. For blood metabolites $1 \mathrm{ml}$ blood was assumed to be $1 \mathrm{~g}$. Blood ATP levels based on dry sediment weight were corrected for volume. For details see 'Discussion'

\begin{tabular}{|c|c|c|c|}
\hline & $\begin{array}{l}\text { Metabolite change } \\
\left(\mu \mathrm{mol} \mathrm{g}{ }^{-1} 12 \mathrm{~h}^{-1}\right)\end{array}$ & $\begin{array}{l}\text { ATP equivalents } \\
\left(\mu \mathrm{mol} \mathrm{g}{ }^{-1} \mathrm{~h}^{-1}\right)\end{array}$ & $\begin{array}{c}\text { Standard whole animal ATP equivalents } \\
\left(\mu \mathrm{mol} 100 \mathrm{~g}^{-1} \mathrm{~h}^{-1}\right)\end{array}$ \\
\hline \multicolumn{4}{|c|}{$6 \%$ air saturation } \\
\hline \multicolumn{4}{|c|}{ Lactate } \\
\hline Liver & 4.06 & 0.51 & 0.32 \\
\hline Muscle & 9.66 & 1.21 & 78.46 \\
\hline Blood & 19.85 & 2.48 & 19.85 \\
\hline Rest & 4.06 & 0.51 & 7.61 \\
\hline \multicolumn{4}{|l|}{ ATP } \\
\hline Liver & 1.29 & 0.11 & 0.07 \\
\hline Blood & 0.92 & 0.08 & 0.61 \\
\hline Rest & 1.29 & 0.11 & 1.62 \\
\hline \multicolumn{4}{|l|}{$\mathrm{PCr}$} \\
\hline \multirow[t]{2}{*}{ Muscle } & 6.87 & 0.57 & 37.24 \\
\hline & & & Total: $\mathbf{1 4 5 . 7 8}$ \\
\hline \multicolumn{4}{|c|}{$\begin{array}{l}12 \% \text { air saturation } \\
\text { Lactate }\end{array}$} \\
\hline Liver & 1.45 & 0.18 & 0.11 \\
\hline Muscle & 3.23 & 0.40 & 26.26 \\
\hline Blood & 4.46 & 0.56 & 4.46 \\
\hline Rest & 1.45 & 0.18 & 2.72 \\
\hline \multicolumn{4}{|l|}{ ATP } \\
\hline Liver & 0.89 & 0.07 & 0.05 \\
\hline Blood & 0.48 & 0.04 & 0.32 \\
\hline Rest & 0.89 & 0.07 & 1.12 \\
\hline \multicolumn{4}{|l|}{$\mathrm{PCr}$} \\
\hline \multirow[t]{2}{*}{ Muscle } & 2.93 & 0.24 & 15.84 \\
\hline & & & Total: \\
\hline
\end{tabular}

evidence for high variability in catecholamine release from chromaffin tissue under hypoxia. In Atlantic cod adrenaline increased significantly in plasma after a gradual lowering of water $\mathrm{pO}_{2}$, whereas after a rapid induction of hypoxia not only adrenaline but also noradrenaline were elevated (Perry et al. 1991). In rainbow trout under $48 \mathrm{~h}$ exposure to moderate hypoxia, adrenaline increased only after $5 \mathrm{~h}$, peaking at $25 \mathrm{~h}$ and returning to normoxic concentrations after $48 \mathrm{~h}$
(Thomas et al. 1991). As far as our experiments with $S$. solea are concerned it should be kept in mind that the fish had been exposed to hypoxia for as long as $12 \mathrm{~h}$, and that catecholamine release might have been low under such an extended exposure. Due to the short biological half-time of catecholamines (less than 10 min; Nekvasil \& Olson 1986), even high initial catecholamine concentrations would have been lowered within the $12 \mathrm{~h}$ of exposure. In the absence of a cate-

Table 4. Solea solea. Aerobic versus anaerobic energy production in sole exposed to 12 h of hypoxia at 6 and $12 \%$ air saturation. Calculations are referred to a standard whole fish of $100 \mathrm{~g}$. ATP production at normoxia $=100 \%$; the percentage of the normoxic rate in parentheses. For details see 'Discussion'

\begin{tabular}{|c|c|c|c|}
\hline & $\begin{array}{c}\text { Normoxia } \\
\left(\mu \mathrm{mol} \text { ATP } 100 \mathrm{~g}^{-1} \mathrm{~h}^{-1}\right)\end{array}$ & $\begin{array}{c}12 \% \text { air saturation } \\
\left(\mu \mathrm{mol} \text { ATP } 100 \mathrm{~g}^{-1} \mathrm{~h}^{-1}\right)\end{array}$ & $\begin{array}{c}6 \% \text { air saturation } \\
\left(\mu \mathrm{mol} \text { ATP } 100 \mathrm{~g}^{-1} \mathrm{~h}^{-1}\right)\end{array}$ \\
\hline Aerobic energy ${ }^{a}$ & $817(100 \%)$ & $546(67 \%)$ & $279(34 \%)$ \\
\hline Anaerobic energy & $0.0(0 \%)$ & $51(6 \%)$ & $146(18 \%)$ \\
\hline Calculated metabolic depression & $0.0(0 \%)$ & $220(27 \%)$ & $392(48 \%)$ \\
\hline
\end{tabular}


cholamine stimulus we would expect, according to Wardle (1978), a 'non-retainment' of lactate in the muscle tissue of the sole. It is not known in this species how fast and under which conditions lactate is released into the circulation from the tissues and vice versa, but our data show that flatfish are capable of having very high blood lactate levels.

\section{Anaerobic metabolism and metabolic depression}

Since we measured the most relevant compounds of energy metabolism, the energy balance of Solea solea during exposure to 12 and $6 \%$ air saturation can be estimated. Two metabolites are particularly important for the calculation of anaerobic energy generation: phosphocreatine (equivalent to 1 ATP) and lactate. Since most of the lactate originated from glycogen, $1 \mathrm{~mol}$ lactate is equivalent to $1.5 \mathrm{~mol}$ ATP. In order to extrapolate concentrations to the whole individual we estimated the relative mass of the tissues. Muscle content of sole is estimated to be around $65 \%$ (Liewes 1984, and own measurements), relative hiver weight of sole was $0.63 \pm 0.31 \%$ (mean $\pm \mathrm{SE}$ ). Blood volume of fish is usually around $5 \%$ (Farrell 1991), and together with the extracellular space around $8 \%$ (Heisler 1986). The remaining metabolically active biomass (heart, gut, kidney, brain) was estimated at $15 \%$ of total body mass, assuming a metabolic activity similar to the liver. On the basis of these assumptions the contribution of anaerobic metabolism to energy production at 12 and $6 \%$ air saturation was calculated to amount to 51 and $146 \mu \mathrm{mol}$ ATP $100 \mathrm{~g}^{-1} \mathrm{~h}^{-1}$, respectively (Table 3 ). Resting metabolic rates in these fish calculated from oxygen consumption were 546 and $279 \mu \mathrm{mol}$ ATP $100 \mathrm{~g}^{-1}$ $\mathrm{h}^{-1}$ (Van den Thillart et al. 1994). Thus estimated total energy production amounted to 598 and $427 \mu \mathrm{mol}$ ATP $100 \mathrm{~g}^{-1} \mathrm{~h}^{-1}$ (Table 4). These values are still below the standard metabolic rate during normoxia of $817 \mathrm{\mu mol}$ ATP $100 \mathrm{~g}^{-1} \mathrm{~h}^{-1}$. Thus at both levels of severe hypoxia anaerobic compensation was far from complete. Although the rate of anaerobic metabolism was higher at 6 than at $12 \%$, the gap was larger at $6 \%$. This gap between total metabolic rate at normoxia and severe hypoxia, called metabolic depression, amounted to 27 and $48 \%$ at 12 and $6 \%$ air saturation, respectively (Table 4). Recently a similar pattern of metabolic depression under hypoxic conditions was described for the marine invertebrates Sipunculus nudus (Hardewig et al. 1991) and Scapharca inaequivalvis (Van den Thillart et al. 1992). For vertebrates this paper is the first to show metabolic depression under hypoxia, indicating that metabolic depression represents a more effective survival strategy than the induction of anaerobic metabolism.
Acknowledgements. We thank Mr G. Vitali for assistance and maintenance of captured animals, and Mag. Ch. Lederer for valuable assistance during part of the biochemical analysis. Suggestions and critical reading by Prof. W. Wieser improved the manuscript. Our thanks are extended to the Centro di Ricerche Marine at Cesenatico (Italy) for use of their facilities during part of this investigation and to Prof. P. Cortesi for organizing the local resources. Funding was provided by the Commission of the European Communities 4th Environment R\&D programme under contract \#EV4V-0122-NL. J.D.V was supported in part by the Österreichische Forschungsgemeinschaft, Vienna, Austria. Communication no. 681 of the Centre for Estuarine and Coastal Ecology.

\section{LITERATURE CITED}

Batty, R. S., Wardle, C. S. (1979). Restoration of glycogen from lactic acid in the anaerobic swimming muscle of plaice Pleuronectes platessa L. J. Fish Biol. 15: 509-519

Bergmeyer, H. U. (ed.) (1984). Methods of enzymatic analysis, 3rd edn, Vol. VI, Metabolites, Part 1, Carbohydrates. Verlag Chemie, Weinheim

Bergmeyer, H. U. (ed.) (1985a). Methods of enzymatic analysis, 3rd edn, Vol. VII, Metabolites, Part 2, Tri- and dicarboxylic acids, purines, pyrimidines and derivatives, coenzymes, inorganic compounds. Verlag Chemie, Weinheim

Bergmeyer, H. U. (ed.) (1985b). Methods of enzymatic analysis, 3rd edn, Vol. VIII, Metabolites, Part 3, Lipids, amino acids and related compounds. Verlag Chemie, Weinheim

Bito, M., Amano, K. (1962). Significance of the decomposition of ATP in fish muscle at temperatures around $-2^{\circ} \mathrm{C}$. Tokai Reg. Fish. Res. Lab. 32: 149-153

Burggren, W., McMahon, B., Powers, D. (1991). Respiratory functions of blood. In: Prosser, C. L. (ed.) Environmental and metabolic animal physiology. Comparative animal physiology, 4th edn. Wiley-Liss, New York, p. 437-508

Dalla Via, G. J., Huber, M., Wieser, W., Lackner, R. (1989). Temperature related responses of intermediary metabolism to forced exercise and recovery in juvenile Rutilus rutilus (L.) (Cyprinidae: Teleostei). Physiol. Zool. 62: $964-976$

Dalla Via, G. J., Lackner, R. (1991). Metaboliten des Intermediärstoffwechsels: Verbesserte Probenaufbereitung mittels einer Mörsermühle. Veröff. Univ. Innsbruck 181: 93-99

Duthie, G. G. (1982). The respiratory metabolism of temperature-adapted flatfish at rest and during swimming activity and the use of anaerobic metabolism at moderate swimming speeds. J. exp. Biol. 97: 359-373

Farrell, A. P. (1991). Circulation of body fluids. In: Prosser, C. L. (ed.) Environmental and metabolic animal physiology. Comparative animal physiology, 4th edn. Wiley-Liss, New York, p. 509-558

Girard, S. S., Milligan, C. L. (1992). The metabolic fate of blood-borne lactate in winter flounder (Pseudopleuronectes americanus) during recovery from strenuous exercise. Physiol. Zool. 65: 1114-1134

Glass, M. L. (1992). Ventilatory responses to hypoxia in ectothermic vertebrates. In: Wood, S. C., Weber, R. E., Hargens, A. R., Millard, R. W. (eds.) Physiological adaptations in vertebrates. Marcel Dekker, New York, $p$. $97-118$

Greaney, G. S., Place, A., Cashon, R., Smith, G., Powers, D. (1980). Time course of changes in enzyme activities and blood respiratory properties of killifish during long-term acclimation to hypoxia. Physiol. Zool. 53: 136-144 
Greaney, G. S., Powers, D. A. (1977). Cellular regulation of an allosteric modifier of fish hemoglobin. Nature 270: 73-74

Hardewig, I., Addink, A. D. F., Grieshaber, M. K., Pörtner, H. O., Van den Thillart, G. (1991). Metabolic rates at different oxygen levels determined by direct and indirect calorimetry in the oxyconformer Sipunculus nudus. J. exp. Biol. 157: 143-160

Härdig, J., Olsson, L. A., Höglund, L. B. (1978). Autoradiography on erythrokinesis and multihemoglobins in juvenile Salmo salar L. at various respiratory gas regimes. Acta physiol. scand. 103: 240-251

Heisler, N. (1986). Acid base regulation in fishes. In: Heisler, N. (ed.) Acid-base regulation in animals. Elsevier, Amsterdam, p. 309-356

Hochachka, P. W., Guppy, M. (1987). Metabolic arrest and the control of biological time. Harvard University Press, Cambridge

Hyvärinen, H., Holopainen, I. J., Piironen, J. (1985). Anaerobic wintering of crucian carp (Carassius carassius L.). I. Annual dynamics of glycogen reserves in nature. Comp. Biochem. Physiol 82A: 797-803

Jackson, D. C. (1968). Metabolic depression and oxygen depletion in the diving turtle. J. appl. Physiol. 24: 503-509

Johansen, K. (1970). Air breathing in fishes. In: Hoar, W. S., Randall, D. J. (eds.) Fish physiology, Vol. IV. Academic Press, New York, p. 361-411

Jones, D. R., Randall, D. J., Jarman, G. M. (1970). A graphical analysis of oxygen transfer in fish. Respir. Physiol. 10: $285-298$

Kramer, D. L., McClure, M. (1982). Aquatic surface respiration, a widespread adaptation to hypoxia in tropical freshwater fishes. Environ. Biol. Fish. 7: 47-55

Kruuk, H. (1963). Diurnal periodicity in the activity of the common sole, Solea vulgaris Quensel. Neth. J. Sea Res. 2 : $1-28$

Lagardère, J. P., Ducamp, J. J., Frikha, L., Sperandio, M. (1988). Ultrasonic tracking of common sole juveniles (Solea vulgaris Quensel, 1806) in a saltmarsh: methods and fish response to some environmental factors. J. appl. Ichthyol. 4: 87-96

Liewes, E. W. (1984). Culture, feeding and diseases of commercial flatfish species. Balkema, Rotterdam

McLeod, T. F., Sigel, M. M., Yunis, A. A. (1978). Regulation of erythropoiesis in the Florida gar, Lepisosteus platyrhinchus. Comp. Biochem. Physiol 60A: 145-150

Milligan, C. L., McDonald, D. G. (1988). In vivo lactate kinetics at rest and during recovery from exhaustive exercise in coho salmon (Oncorhynchus kisutch) and starry flounder (Platichthys stellatus). J. exp. Biol. 135: 119-131

Milligan, C. L., Wood, C. M. (1987). Muscle and liver intracellular acid-base status after strenuous activity in the inactive, benthic starry flounder (Platichthys stellatus). Physiol. Zool. 60: 54-68

Nekvasil, N. P., Olson, K. R. (1986). Plasma clearance, metabolism, and tissue accumulation of ${ }^{3} \mathrm{H}$-labelled catecholamines in trout. Am. J. Physiol. 259: R519-R525

Nikinmaa, M. (1986). Control of red cell pH in teleost fish. Ann. zool. fenn. 23: 223-235

Nikinmaa, M. (1990). Vertebrate red blood cells. Adaptations of function to respiratory requirements. Springer-Verlag, Berlin

Nilsson, G. E. (1990). Long-term anoxia in crucian carp: changes in the level of amino acid and monoamine neurotransmitters in the brain, catecholamines in chromaffin tissue, and liver glycogen. J. exp. Biol. 150: 295-320

Nilsson, G. E., Lutz, P. L. (1993). Role of GABA in hypoxia tolerance, metabolic depression and hibernation - possible links to neurotransmitter evolution. Comp. Biochem. Physiol. 105C: $329-336$

Nilsson, G. E., Rosén, P., Johansson, D. (1993). Anoxic depression of spontaneous locomotor activity in crucian carp quantified by a computerized imaging technique. J exp. Biol. 180: 153-162

Nilsson, S. (1983). Zoophysiology, Vol. 13, Autonomic nerve function in the vertebrates. Springer-Verlag, Berlin

Nowlan, S. S., Dyer, W. J. (1974). Maximum rates of glycolysis and breakdown of high energy phosphorus compounds in prerigor cod muscle at specific freezing temperature between -1 and $-4{ }^{\circ} \mathrm{C}$. J. Fish. Res. Bd Can. 31: 1173-1179

Perry, S. F., Fritsche, R., Kinkead, R., Nilsson, S. (1991). Control of catecholamine release in vivo and in situ in the Atlantic cod (Gadus morhua) during hypoxia. J. exp. Biol. 155: $549-566$

Peterson, M. S. (1990). Hypoxia-induced physiological changes in two mangrove swamp fishes: sheepshead minnow, Cyprinodon variegatus (Lacepede) and sailfin molly, Poecilia latipinna (Lesueur). Comp. Biochem. Physiol. 97 A: $17-21$

Randall, D. J., Daxboeck, C. (1984). Oxygen and carbon dioxide transfer across fish gills. In: Hoar, W. S., Randall, D. J. (eds.) Fish physiology. Academic Press, New York, p. 263-314

Randall, D. J., Perry, S. F. (1992). Catecholamines. In: Hoar, W. S., Randall, D. J., Farrell, A. P. (eds.) Fish physiology, Vol. 12B. Academic Press, London, p. 255-299

Rinaldi, A., Montanari, G., Ghetti, A., Ferrari, C. R. (1993) Anossie nelle acque costiere dell'Adriatico nord-occidentale. Loro evoluzione e conseguenze sull'ecosistema bentonico. Biologia mar. (Suppl. Notiz. Soc. [tal. Biol. mar.) 1: $79-89$

Schurmann, H., Steffensen, J. F., Lomholt, J. P. (1991). The influence of hypoxia on the preferred temperature of rainbow trout Oncorhynchus mykiss. J. exp. Biol. 157: $75-86$

Storey, K. B. (1988). Suspended animation: the molecular basis of metabolic depression. Can. J. Zool. 66: 124-132

Sureau, D., Lagardère, J. P. (1991). Coupling of heart rate and locomotor activity in sole Solea solea (L.), and bass, Dicentrarchus labrax (L), in their natural environment by using ultrasonic telemetry. J. Fish Biol. 38: 399-405

Tetens, V., Lykkeboe, G. (1985). Acute exposure of rainbow trout to mild and deep hypoxia: $\mathrm{O}_{2}$ affinity and $\mathrm{O}_{2}$ capacitance of arterial blood. Respir. Physiol. 61: 221-235

Thomas, S., Kinkead, R., Wood, C. M., Walsh, P. J., Perry, S. F. (1991). Desensitization of adrenaline-induced red blood cell $\mathrm{H}^{+}$extrusion in vitro after chronic exposure of rainbow trout (Salmo gairdneri) to moderate environmental hypoxia. J. exp. Biol. 156: 233-248

Turner, J. D., Wood, C. M., Höbe, H. (1983). Physiological consequences of severe exercise in the inactive benthic flathead sole (Hippoglossoides elassodon): a comparison with the active pelagic rainbow trout (Salmo gairdnen). J. exp. Biol. 104: 269-288

Van den Thillart, G., Dalla Via, J. (1993). Influence of longterm hypoxia exposure on aerobic and anaerobic metabolism of Solea solea. Biologia mar. (Suppl. Notiz. Soc. Ital. Biol. mar.) 1: $103-108$

Van den Thillart, G., Dalla Via, J., Vitali, G., Cortesi, P. (1994). Influence of long-term hypoxia exposure on the energy metabolism of Solea solea. I. Critical oxygen levels for aerobic and anaerobic metabolism. Mar. Ecol. Prog. Ser. 104: $109-117$

Van den Thillart, G., Smit, H. (1984). Carbohydrate metaboism of goldfish (Carassius auratus L.). Effects of long-term 
hypoxia-acclimation on enzyme patterns of red muscle, white muscle and liver. J. comp. Physiol. B154: 477-486

Van den Thillart, G., Van Lieshout, G., Storey, K., Cortesi, P., De Zwaan, A. (1992). Influence of long-term hypoxia on the energy metabolism of the haemoglobin-containing bivalve Scapharca inaequivalvis: critical $\mathrm{O}_{2}$ levels for metabolic depression. J. comp. Physiol 162B: 297-304

Van den Thillart, G., Verbeek, R. (1991). Anoxia-induced oxygen debt of goldfish (Carassius auratus L.). Physiol. Zool. 64: $525-540$

Van Waversveld, J., Addink, A. D. F., Van den Thillart, G. (1989). Simultaneous direct and indirect calorimetry on normoxic and anoxic goldfish. J. exp. Biol. 142: 325-335

Wardle, C. S. (1978). Non-release of lactic acid from anaerobic swimming muscle of plaice Pleuronectes platessa L.: a stress reaction. J. exp. Biol. 77: 141-155

Weber, R. E. (1982). Intraspecific adaptation of hemoglobin function in fish to oxygen availability. In: Addink, A. D. F., Spronk, N. (eds.) Exogenous and endogenous influences on metabolic and neural control. Pergamon Press, Oxford, p. $87-102$

This article was presented by W. Wieser, Innsbruck, Austria
Wood, C. M., McMahon, B. R., McDonald, D. G. (1977). An analysis of changes in blood $\mathrm{pH}$ following exhaustive activity in the starry flounder, Platichthys stellatus. J. exp. Biol. 69: 173-185

Wood, C. M., Walsh, P. J., Thomas, S., Perry, S. F. (1990) . Control of red blood cell metabolism in rainbow trout after exhaustive exercise. J. exp. Biol. 154: 491-507

Wood, S. C. (1980). Adaptation of red blood cell function to hypoxia and temperature in ectothermic vertebrates. Am. Zool. 20: 163-172

Wood, S. C. (1991). Interactions between hypoxia and hypothermia. A. Rev. Physiol. 53: 71-85

Wood, S. C., Malvin, G. M. (1992). Behavioural hypothermia - an adaptive stress response. In: Wood, S. C., Weber, R. E., Hargens, A. R., Millard, R. W. (eds.) Physiological adaptations in vertebrates. Respiration, circulation, and metabolism. Marcel Dekker, New York, p. 295-312

Wright, P. A., Perry, S. F., Moon, T. W. (1989). Regulation of hepatic gluconeogenesis and glycogenolysis by catecholamines in rainbow trout during environmental hypoxia. J. exp. Biol. 147: 169-188

Manuscript first received: January 14, 1994

Revised version accepted: May 5, 1994 